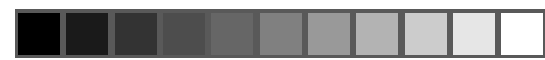

\title{
1755, o ano da virada na Amazônia portuguesa
}

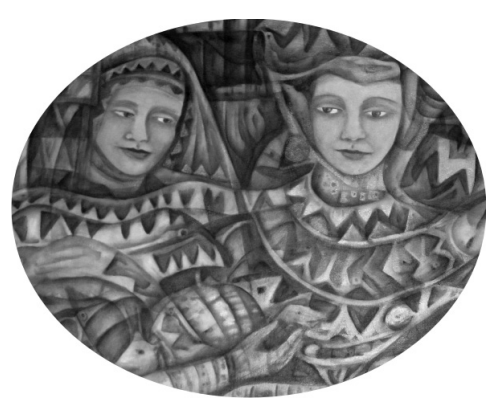

Francisco Jorge dos Santos*

Patrícia Maria Melo Sampaio***

\section{Resumo}

Este artigo pretende focalizar 1755 como o ano em que a Coroa portuguesa redefiniu política e administrativamente a sua relação colonizadora com a Amazônia, até então vista como um domínio de pouca importância no interior do seu Império Colonial. Por conseguinte, será analisado o contexto e os elementos constitutivos responsáveis por essa mudança de atitude metropolitana em suas dimensões históricas e culturais, os quais concorreram para o surgimento de uma nova feição da sociedade luso-amazônica.

Palavras-chave: Legislação colonial. Amazônia portuguesa. Índios aldeados. Miscigenação.

\section{Resumé}

L'article focalise 1755 comme l'année où la Couronne portugaise a changé d'un point de vue polítique et administratif leur relation de colonisation avec l'Amazonie, jusq'álors vue comme un domaine sans grande importance à l'intérieur de leur Empire Colonial. Ainsi, sera analysé le contexte et les éléments responsables pour ce changement d'atitude métropolitaine dans leurs dimensions historiques et

\footnotetext{
* Doutorando do Programa de Pós-Graduação Sociedade e Cultura na Amazônia - PPGSCA da Universidade Federal do Amazonas/ UFAM e Professor do Departamento de História da Universidade Federal do Amazonas/UFAM.

** Professora-orientadora do Programa de Pós-Graduação Sociedade e Cultura na Amazônia - PPGSCA da Universidade Federal do Amazonas/UFAM e Professora do Departamento de História da Universidade Federal do Amazonas/UFAM.

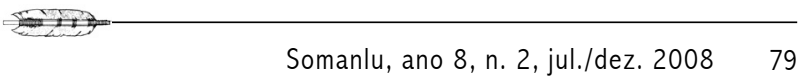


culturalles, que ont concouru pour le surgissement de une nouvelle face de la societé luso-amazonique.

Mots-clé: Législation coloniale. Amazonie portugaise. Indiens de village. Métissage

Consideramos o ano de 1755 como o ano da "virada" pelo fato de que, no seu curso, a Coroa portuguesa redefiniu um processo histórico de colonização que já durava quase um século e meio na Amazônia. Essa virada conjugou situações tanto externas quanto internas e estas, por sua vez, responderam e influíram dialeticamente nas determinações metropolitanas.

Desse modo, o ano em foco pode ser considerado como um "divisor de águas" em termos político-administrativo, pois nesse período foram publicados os diplomas legislativos que puseram fim a toda estrutura vigente até então. Portanto, foi um ano decisivo para a construção de um padrão do domínio lusitano jamais visto, cuja conseqüência fundamental consistiu na modelagem da sociedade colonial lusoamazônica, cujas implicações históricas e culturais consolidaram-se ao longo do tempo.

Cinco são as peças legislativas determinantes neste processo, cronologicamente: 1. a Carta-régia, de 3 de março de 1755, que criou a Capitania de São José do Rio Negro; 2. o Alvará de Lei, de 4 de abril de 1755, que "declara os vassalos do Reino da América que se casarem com índias não ficarão com a infâmia alguma, antes serão preferidos nas terras em que se estabelecerem, etc."; 3. a Lei, de 6 de junho de 1755, que "restituiu aos índios do Grão-Pará e Maranhão a liberdade de suas pessoas, bens e comércio na forma que nela se declara"; 4. a Instituição da Companbia Geral do Comércio do Grão-Pará e Maranbão, de 6 de junho de 1755; 5. o Alvará com força de Lei, de 7 de junho de 1755, "cassando a jurisdição temporal dos Regulares sobre os índios do Grão-Pará e Maranhão".

\section{Capitania do Rio Negro}

O simples ato da criação da Capitania do Rio Negro já seria um fato significativo historicamente, pois, além de acelerar a produção do espaço nas margens dos rios da região, quase esvaziadas pelo processo da conquista, delineou os contornos primordiais do território e das instituições político-administrativas e jurídicas das

80 Somanlu, ano 8, n. 2, jul./dez. 2008 
sociedades amazonenses, que se desenvolveram diacronicamente no interior da própria Capitania do Rio Negro, nas comarcas do Rio Negro e Alto Amazonas, na Província do Amazonas e no Estado do Amazonas.

Um conjunto bem articulado de fatores concorreu para que a Coroa portuguesa se dignasse a legislar em favor da criação de um aparelho de Estado nos confins da Amazônia ${ }^{1}$, tais como: a distância em que se encontrava a região em relação aos poderes de decisões, instalados em Belém ou em São Luís; a expectativa de uma invasão holandesa via rio Tacutu/Branco; a política do princípio do uti possidetis, selada no Tratado de Madri; o fato da própria demarcação de limites dos domínios ibéricos na América do Sul; e, ainda, a suspeição de manobras perigosas por parte dos missionários contra os interesses da Coroa portuguesa. Em suma, esses fatores deveriam ser disciplinados para que se pudesse garantir a soberania de Portugal nesta parte da América, completamente abandonada, cobiçada por holandeses, espanhóis e à mercê daqueles que poderiam criar futuros embaraços locais (Cf. REIS, 1989; MENDONÇA, 2005).

A presença lusitana mais amiúde nessa região foi responsável pela geração de toda sorte de necessidades e preocupações, antes pouco perceptíveis à ótica da Coroa portuguesa. Porém, essa mudança de foco não foi genuinamente gerada aí; antes, teve a sua geratriz numa conjuntura vivida na sua exterioridade européia e luso-brasileira, quando decisões foram tomadas a fim de debelar uma grande crise institucional experimentada pelo Reino de Portugal, face aos seus acordos internacionais que se tornaram desastrosos para sua economia. No além-mar, deve-se creditar aos conflitos territoriais e bélicos que, historicamente, tinham como palco a região meridional da América portuguesa, os quais empurram Portugal e Espanha para uma definição de fronteiras territoriais; assim sendo, a região em tela entrou no espírito das demarcações de limites, aos sabores conjunturais externos.

Desse modo, os portugueses construíram na região um problema que teriam que resolver: tinham que dar conta da produção de riqueza para sanar as mazelas econômicas do Reino, ao mesmo tempo em que tinham, também, que engendrar uma sociedade luso-amazônica - parodiando um antigo dito popular - "para castelhano ver", face às cláusulas do Tratado de Madri. Um dos caminhos para essa resolução foi a criação da Capitania do Rio Negro, em março de 1755.

Com a implantação da Capitania do Rio Negro, em maio de 1758, os problemas produzidos pela presença portuguesa, burocraticamente, estariam sendo

Somanlu, ano 8, n. 2, jul./dez. 2008 
solucionados, pois já havia ali um governo instituído para manter a ordem e proteger o bem comum dos portugueses, evidentemente, em detrimento da ordem e do bem comum das populações nativas.

A partir de uma perspectiva européia, a presença do Estado na região teria fomentado, nas quatro décadas subseqüentes, um bom grau de desenvolvimento econômico e social, considerando este último como o aumento demográfico nas povoações, à custa do processo de "civilização do indígena", e igual crescimento dos núcleos coloniais. Por exemplo, no início da década de 1760, a Capitania do Rio Negro contava com um total de um pouco mais de 5.000 habitantes. Esse número foi aumentando em cada ano (Ver Tabela 1).

Tabela 1

\begin{tabular}{|c|c|c|c|c|}
\hline \multicolumn{5}{|c|}{ População da Capitania do Rio Negro (1775-1796) } \\
\hline $\begin{array}{l}\text { Ano do } \\
\text { Censo }\end{array}$ & $\begin{array}{c}\text { Total da } \\
\text { população }\end{array}$ & $\begin{array}{l}\text { Indios } \\
\text { aldeados }\end{array}$ & $\begin{array}{c}\text { Brancos e } \\
\text { descendentes }\end{array}$ & $\begin{array}{l}\text { Negros } \\
\text { escravos }\end{array}$ \\
\hline 1775 & 11.749 & 10.620 & 936 & 193 \\
\hline 1781 & $12.288^{1}$ & 10.620 & 1.475 & 193 \\
\hline 1790 & 12.964 & 11.320 & 1.176 & 468 \\
\hline 1793 & 13.728 & 11.789 & 1.365 & 574 \\
\hline 1796 & 14.232 & 12.154 & 1.485 & 492 \\
\hline
\end{tabular}

Fonte: $\left(^{*}\right)$ Reis, 2006; Sampaio, 1985. Nesse somatório não entraram 1.019 índios distribuídos em cinco aldeamentos do rio Branco.

Quanto ao número de núcleos coloniais, até o final do século XVIII, esta Capitania contava com um pouco mais de meia centena de unidades (vilas, lugares, aldeamentos, fortalezas e pesqueiros reais).

Ao proceder à análise acerca da economia colonial portuguesa, Arthur C. F. Reis, em contextos diferenciados, proferiu:

a) Portugal, dentro do espírito de sua época, conduzindo com acerto seu domínio ultramarino do extremo norte na América, realizava, no aspecto econômico, hábil política colonizadora. Sua economia foi assistida, orientada (REIS, 2006, p. 42).

b). Nada se realizou, no campo da produção, que não tivesse sido controlado, orientado pelo Estado. A produção se fazia sob fiscalização, sob a direção do Estado (REIS, 1993, p.109).

82 Somanlu, ano 8, n. 2, jul./dez. 2008 
De acordo com os analistas do período, a Capitania do Rio Negro teria alcançado os maiores indicadores econômicos durante a governação de Manuel da Gama Lobo d'Almada (1788-1799), sugerindo um constante crescimento em todos os setores da economia. No entanto, pensamos que ainda é cedo para se corroborar essas conclusões face ao baixo volume de pesquisas acerca do período e, sobretudo, desta temática.

Portanto, a Carta-régia, de 3 de março de 1755, que criou a Capitania de São José do Rio Negro, constituiu um elemento da virada, pois estabeleceu os primeiros parâmetros legais para o desenvolvimento de um modus vivendi à moda européia sobre outro culturalmente indígena, consolidando, assim, a presença do Estado português nesta parte da Amazônia.

\section{Liberdade de Casamentos}

Desde os primórdios da colonização portuguesa, a relação matrimonial ou de concubinato entre índios e brancos foi sempre assunto complicado e proibido. Por exemplo, em meados do século XVI, o padre Manuel da Nóbrega, em carta enviada a Lisboa, dizia que deveriam vir órfãs e meretrizes, pois, residindo no Brasil, umas casariam com os brancos de diferentes condições sociais, os ricos se casariam com as primeiras e os outros com as segundas. Um outro jesuíta congratulase, em uma carta, pelo fato de vários homens solteiros terem deixado suas índias e se casado com filhas de homens brancos (Cf. SILVA, 1984, p.18).

Na segunda metade do século XVII, a mesma preocupação eclesiástica e civil da América portuguesa meridional persiste na Amazônia. Por exemplo, uma legislação desse período determinou:

Nas aldeias não poderão assistir, nem morar outras algumas pessoas, mais que os índios e suas famílias, pelo dano que fazem nelas, e achando-se que nelas moram, ou assistem algum branco, ou mameluco, o governador os fará tirar, e apartar das ditas aldeias, ordenando-lhes, que não tornem mais a elas, e os que lá forem, ou tornarem depois desta proibição, que se mandará publicar com editais, e bandos por todo Estado, sendo peões serão açoitados publicamente pelas ruas da cidade, e se forem nobres, serão degredados em cinco anos para Angola, e em um, e outro caso sem apelação" (Regimento

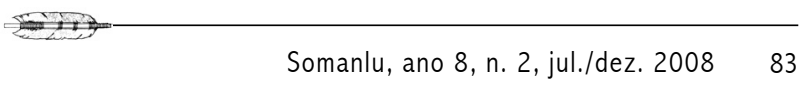


das Missões do Estado do Maranhão e Pará, de 21 de dezembro de 1686. Ortografia atualizada. (BEOZZO, 1983, p. 114-120).

Ao que parece, a preocupação dos missionários (aqui desconsideramos o ponto de vista civil) com a miscigenação seria o fato de que esse processo contribuía para tirar os índios de sua tutela.

Portanto, na América portuguesa, havia proibição de casamento entre índios e portugueses; no entanto, movida por uma série de fatores, em meados do século XVIII, a Coroa portuguesa teve que abolir esse impedimento de relação, pois teria, como já dissemos, "que engendrar uma sociedade luso-amazônica". Tal agenda passou a fazer parte do conjunto de medidas para a resolução dos problemas do Reino e do Império; por conseguinte, o rei D. José I, em 4 de abril de 1755, sancionou o Alvará que disciplinou a matéria.

Eis o trecho capital do diploma régio:

Sou servido declarar que, os meus vassalos deste reino e da América, que casarem com as índias dela não ficam com a infâmia alguma, antes se farão dignos de minha real atenção, e que nas terras, em que se estabeleceram, serão preferidos para aqueles lugares, e ocupações, que couberem na graduação das suas pessoas, e que seus filhos, e descendentes serão hábeis, e capazes de qualquer emprego, honra, ou dignidades, sem que necessitem de dispensa alguma, em razão destas alianças. (BIBILOTECA DIGITAL, 2009 Ortografia atualizada).

Entretanto, esses "vassalos deste reino e da América" estavam proibidos de casar com negros e negras cativos ou escolhê-los como padrinhos e madrinhas de batismo e confirmação. Essa legislação proibia ainda que os filhos desses novos casais fossem chamados de "caboclos", igualando-os, teoricamente, aos outros vassalos brancos. De igual modo, as mulheres portuguesas que casassem com índios os seus filhos e descendentes gozariam dos mesmos direitos e vantagens de ser vassalo da Coroa portuguesa (Cf. FLEXOR, 2002, p.169).

De acordo com Ângela Domingues, o processo legislativo relacionado ao casamento entre os vassalos naturais e os reinóis no Grão-Pará e Maranhão, na Índia e em Macau era similar. "A intenção era semelhante: formar um grupo de 
indivíduos que fizessem a ligação entre as duas sociedades, a colonial e a indígena, tanto pelo nascimento, quanto pela formação" (DOMINGUES, 2000, p. 40).

Em correspondência com a Corte lusitana, Mendonça Furtado se manifesta com satisfação sobre a legalidade desses casamentos, no entanto apresenta uma mista pitada de pessimismo com otimismo quanto à execução de fato da legislação devido os seus opostos provocados pela régia medida:

Também me não deixa menos vaidoso o ter V.Sa. já antes proposto projeto da união dos europeus com os índios, julgando como na verdade é ser este um dos meios para se civilizarem estas infelizes gentes e povoar-se muita parte deste larguíssimo e certamente não compreendido em nosso país [...]././ Nos casamentos tenho trabalhado quanto cabe no possível, e tenho até agora adiantado bem pouco [...] e bem vê V.Sa. que contra a maré e ventos não se pode fazer grande caminho, eu porém não esmoreço e vou fazendo constantemente o que posso (CARTA DE FRANCISCO XAVIER DE MENDONÇA FURTADO para o desembargador Gonçalo José da Silva Preto. Arraial de Mariuá, 12 de junho de 1755. In: MENDONÇA, 2006, tomo 2, p. 432-437).

A concepção de uma "sociedade luso-amazônica", ou como outros dizem "lusitanização da Amazônia”, produziu conseqüências históricas que aceleraram o processo de formação de um perfil cultural para a região, o qual - guardadas as devidas proporções - alcançou o tempo presente, pois selou a formação de uma cultura miscigenada, antigo receio dos missionários. No entanto, é bom que se diga que o início desse processo é muito anterior a esse período, pois dele faz parte, também, aquilo que então se denominava "casamento pela lei da natureza" ou, de maneira pejorativa, concubinato ou mancebia, que talvez seja a sua verdadeira gênese ${ }^{2}$.

A legislação que permitiu a união matrimonial entre brancos e índios, ao que parece, definiu bem qual seria esse "índio", na medida em que os índios do contato cotidiano eram os "índios aldeados" , já incorporados às missões ou aos aldeamentos, depois às vilas ou lugares pombalinas, diferentes dos "índios gentios", ou dos "índios tribais”, que estariam ainda fora do convívio dito civilizado. 
O índio aldeado, na literatura especializada, recebeu diversos conceitos, tais como: "destribalizado", "aculturado", "genérico", "tapuio", inclusive "ribeirinho" Aqui trabalharemos com o de "tapuio", que foi definido conceitualmente por José Veríssimo, ainda no século XIX, e redescoberto por Carlos de Araújo Moreira Neto, na década de 1980. O prefaciador da obra de Moreira Neto disse o seguinte: "Eis um estudo monográfico que trata especificamente do assim chamado tapuio e procura cuidadosamente definir este grupo social e étnico assim como o processo político que o gerou" (MOREIRA NETO, 1988, p. 11) ${ }^{6}$

A essa população que habita as margens do grande rio e seus numerosos affluentes, vivendo a nossa vida, contribuindo para a nossa receita, trabalhando na nossa industria, e que não é nem índio puro, o brazílico-guarani, nem o seu descendente em cruzamento com o branco, o mameluco, é que, pareceme, cabe o nome de tapuio [...]/./ Forçados a assimilar costumes, crenças, idéas, lingua, tudo enfim, inteiramente diverso dos seus, o resultado das uniões entre indivíduos de sua raça, dentro já do nosso meio social e sob a sua influência, foi um typo diferente d'ella (VERÍSSIMO, 1887, p. 299-300).

Os trechos acima dão a definição clássica para o tapuio, segundo José Veríssimo. Por conseguinte, Moreira Neto foi buscar suas raízes históricas nos aldeamentos das Ordens religiosas dos séculos XVII e XVIII, por entender que era a missão "o centro por excelência de destribalização e de homogeneização deculturativa daqueles restos de nações menos bravias, concentrado nos aldeamentos catequético. O produto final é o índio privado de sua identidade étnica, o tapuio" (MOREIRA NETO, 1988, p. 23) 7 .

Seguindo a conceituação do estudioso paraense, Moreira Neto consolidoua nos seguintes termos:

O tapuio pode ser definido como membro de um grupo indígena que perdeu socialmente o domínio instrumental e normativo de sua cultura aborígine, substituindo-a por elementos de uma ou várias tradições culturais, que se misturam aos traços residuais da língua e da cultura originais (MOREIRA NETO, 1988, p. 79). 
Portanto, o tapuio entraria como mais um elemento para compor com o branco a tarefa de "lusitanizar" a Amazônia, a partir dos enlaces matrimoniais, permitidos pela Igreja e pelo Estado. Entretanto, parece que algo saiu errado nesses matrimônios que deveriam lusitanizar esta região, pois, vinte anos depois da sua legalização, um funcionário graduado da Coroa portuguesa lançava o seguinte desapontamento: "Os casamentos dos Brancos, que tanto persuadiu a Lei de Abril de 1755, tem sido pela maior parte pouco afortunados; porque em lugar de as Índias tomarem os costumes dos Brancos, estes têm adotados os daquelas" (SAMPAIO, 1985, p. 127).

Independentemente do desapontamento do ouvidor Francisco Xavier Ribeiro de Sampaio, o barco da miscigenação navegou, talvez não pelas alianças com os brancos, pois em termos percentuais o seu quantitativo sempre fora irrisório, pelo menos na Capitania do Rio Negro; como já apontamos acima, até o final do século XVIII esteve em torno de 10\%. Na fase brasileira, em 1840, a Comarca do Alto Amazonas (antiga Capitania do Rio Negro) se apresentava com uma população de um pouco mais de 40.000 habitantes. Esta cifra decomposta em percentuais ficaria assim: 58\% indígenas (tapuios); $26 \%$ mamelucos; $9 \%$ brancos; $4 \%$ mestiços e 3\% escravos (negros) (Cf. AMAZONAS, 1984, Apêndice).

Desse modo, seria plausível considerar que o barco da mesclagem foi pilotado pelos tapuios que se amalgamaram com outros tipos étnicos que José Veríssimo descreveu para Amazônia do século XIX: o branco, o negro e os mestiços (mameluco, mulato, curiboca e cafuzo). Seria lícito sugerir que, com a primeira grande imigração nordestina para a Amazônia no terceiro quartel daquele século, esse processo tenha sido acelerado ${ }^{8}$.

Tal processo produziria um novo desenho populacional da região. Partindo do Maranhão até os limites ocidentais brasileiros, verifica-se que a cultura e a coloração da tez humana vão se modificando a partir do fator histórico colonial; os núcleos europeizados, por exemplo: na grande calha do Amazonas/Solimões, nos médios cursos dos rios Tapajós, Madeira, Negro, e em todo o rio Branco, verifica-se uma população preponderantemente mestiça ou "caboca"; enquanto que, nos rios Purus e Juruá, o mesmo fenômeno não ocorreu, pelo menos até boa parte do século XX.

Se a Lei de 4 de abril de 1755 não teve o efeito esperado pelos colonizadores, no que diz respeito ao casamento de branco com índio, foi eficaz nos enlaces matrimoniais entre os vassalos brancos e os tapuios, além de tornar essa união civil-religiosa livre e universal na colônia, que se estendeu ao longo do tempo.

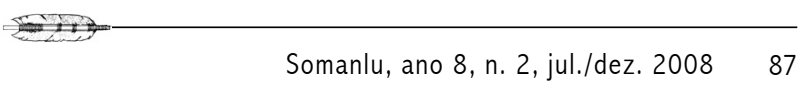




\section{Liberdade e Administração dos índios}

A liberdade dos índios, proporcionada pela Lei de 6 de junho de 1755, diferentemente dos sub-temas acima, já foi por demais avaliada por especialistas das diversas áreas das ciências humanas e sociais. Aqui, no entanto, vamos pôr em relevo o que faz dela um dos elementos da "virada" que se iniciou em 1755.

Leis que promoviam liberdade aos índios na Colônia foram várias ao longo do período colonial; por exemplo: o Alvará de 10 de novembro de 1647, que dispôs que os índios pudessem servir e trabalhar com quem lhes parecesse e melhor lhes pagasse pelo seu trabalho, estabelecendo, dessa forma, um mercado livre de trabalho; a Lei de $10^{\circ}$ de abril de 1680, que mandou processar os que cativassem índios e pôr em liberdade os índios cativos; o Regimento das Missões de 21 de dezembro de 1686, que fixou o tempo de serviço dos índios fora das aldeias, no Maranhão e no Pará, e definiu critérios para o pagamento do salário dos índios retirados das aldeias.

A copiosa ação legislativa da Coroa portuguesa para normatizar a sua política indigenista parecia que estava ao sabor das correlações de força políticas na Colônia, pois ora legislava em favor dos moradores, ora em favor dos padres, o que já se chamou de uma verdadeira "ciranda legislativa". Estaria, portanto, administrando questões de interesse de segmentos sociais.

Agora, a ação legislativa da Coroa portuguesa, em 1755, toma um rumo inteiramente diferente, pois os interesses não seriam mais de cunho particular, mas de Estado. O governo que ora administrava o aparelho de Estado português precisava, como já dissemos acima, "dar conta da produção de riqueza, para sanar as mazelas econômicas do Reino", visto que, enquanto o grosso da força de trabalho, potencialmente produtora de riqueza, estivesse sob o controle dos padres ou dos moradores, seria impossível atingir-se qualquer meta nesse sentido.

Sem entrar no mérito das conseqüências imediatas e duradouras, no que diz respeito à superexploração da força de trabalho dos índios, tema já muito debatido, a Lei de liberdade dos indios, como ficou conhecida, inaugurou algo historicamente indelével. Salvo em alguns casos localizados, a partir daí, manteve-se na Amazônia e no Brasil uma política indigenista contrária à escravidão indígena, que se estendeu para além do período colonial. Vejamos, por exemplo, a que foi determinada pela Carta régia de 12 de maio de 1798, o Regulamento das Missões de catequese e civilização dos indios, de 24 de julho de 1845, já no período imperial. No Brasil republicano: houve o

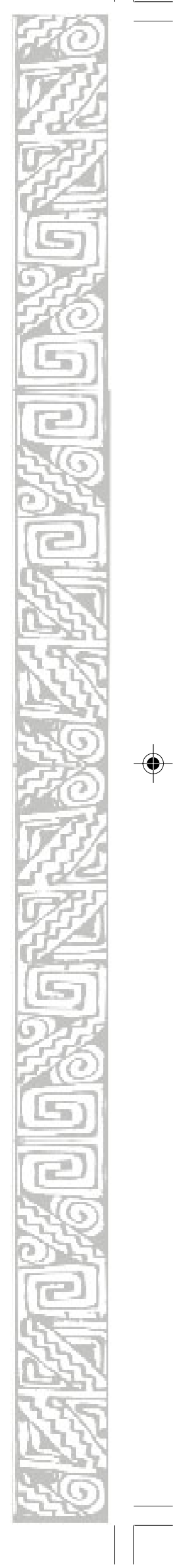


Serviço de Proteção ao Índio, de 1910; a Fundação Nacional do Índio, de 1967; e os artigos 231 e 232 da Constituição Federal de 1988. Todas essas manifestações oficiais mantiveram o princípio fundamental da política indigenista de 1755 , acrescido da tutela do Estado.

A tutela introduzida no período pós-1755 vai, inclusive, diminuir a mobilidade jurídica dos índios, na medida em que surgiram figuras intermediárias nas ações indígenas, diferentemente do que preconizava aquela Lei. Por exemplo, no item liberdade pessoal, os índios deveriam, segundo Ângela Domingues,

Usufruir de um tratamento idêntico concedido aos luso-brasileiros, porque o seu estatuto era o de súdito do monarca. Dessa forma, integravam-se os indígenas nas cadeias jurídicas normais, podendo, como qualquer outro indivíduo, endereçar ao rei, ao governador ou aos tribunais petições, pretensões e queixas se considerassem que seus direitos tinham sido infringidos ou desrespeitados (DOMINGUES, 2000, p, 43).

A publicação do Alvará com força de Lei, de 7 de junho de 1755, que aboliu a administração temporal dos padres sobre os índios do Grão-Pará e Maranhão, foi condição sine qua non para a efetiva aplicação da Lei de liberdade dos indios, pois, na medida em que esta os tornou "Vassalos d'El-Rei" com direitos e deveres equiparados aos reinóis ou luso- brasileiros, deu-lhes as prerrogativas de exercer cargos em todos os setores da administração pública colonial.

Ao mesmo tempo, os aldeamentos ou missões eram transformados em Vila e Lugares, que perderiam as nomenclaturas em lingua geral, para receberem nomes das regiões de Portugal, por exemplo: a Missão de Trocano tornou-se Vila de Borba, a Nova; a Missão de Santa Tereza de Tefé tornou-se Vila de Ega; a Missão de Tapajós tornou-se Santarém; a Missão de Santo Elias do Jaú tornou-se Lugar de Airão; a Missão de Sant'Ana de Coari tornou-se Lugar de Alvelos etc.

A lei deu uma nova forma ao governo temporal dos índios. Ela aboliu completamente o poder administrativo dos missionários de qualquer ordem religiosa sobre os aldeamentos indígenas e determinou que nas Vilas fossem preferidos, para Juízes Ordinários, Vereadores e Oficiais de Justiça, os índios naturais delas e dos seus distritos, sendo idôneos, e que as aldeias independentes das vilas fossem governadas pelos respectivos Principais, que teriam por subalternos os Sargentos-mores, Capitães, Alferes e meirinhos de suas nações (Cf. MALHEIRO, 1944, p. 282). 
Esses diplomas régios, portanto, inseriram jurídica e socialmente os índios na sociedade colonial portuguesa. O modo como estes novos protagonistas vão exercer as funções nos respectivos cargos públicos já foi objeto de outras reflexões elaboradas no seio da historiografia amazônica; por exemplo, sobre a ascensão aos cargos, diz o historiador Mauro C. Coelho:

Para a composição das câmaras das vilas, fora garantida a eleição de indígenas. Assim, em 1761, as Vilas de Melgaço e Portel elegeram, para os cargos de juízes, os índios Alexandre Mascarenhas e Vital da Costa e, para vereadores, os índios Pedro Mascarenhas, Pautilo Pitta, João de Barros e Paullo da Silva. Em 1764, na Vila de Salvaterra, dos seis juízes ordinários, quatro eram índios e seis, dos nove vereadores, também (COELHO, 2006, p. 124).

$\mathrm{Na}$ Capitania do Rio Negro, por ocasião da elevação da aldeia Mariuá à categoria de vila, com a denominação de Vila de Barcelos, em 1758, foram nomeados para a composição da Câmara, entre outras autoridades municipais, dois juízes ordinários, um deles era o Principal dos Manaus, Manuel de Vasconcelos Camandri (Cf. FERREIRA, 2007, p. 204).

Sobre o desempenho das funções, afirma Ângela Domingues:

Já no início de centénio seguinte, se continuava a reconhecer que a inoperância do funcionamento camerário era devida à falta de preparação de seus membros. [...] a maior parte dos juizes ordinários era iletrado e que se apropriavam do cargo para beneficiar pessoalmente do seu exercício (DOMINGUES, 2000, p, 160).

Sobre a complexidade gerada pelas ocupações de cargos públicos pelos índios, Patrícia Melo Sampaio analisou uma dessas situações:

Em 1803, o governador da Capitania de São José do Rio Negro, José Antônio Salgado (1801-1804), estava com um grande problema nas mãos: por conta de uma ordem recémchegada de Lisboa, cabia-lhe dar baixa imediata àqueles oficiais cujas patentes não possuíssem confirmação régia. A dificuldade era que a maioria dos homens sob seu comando 

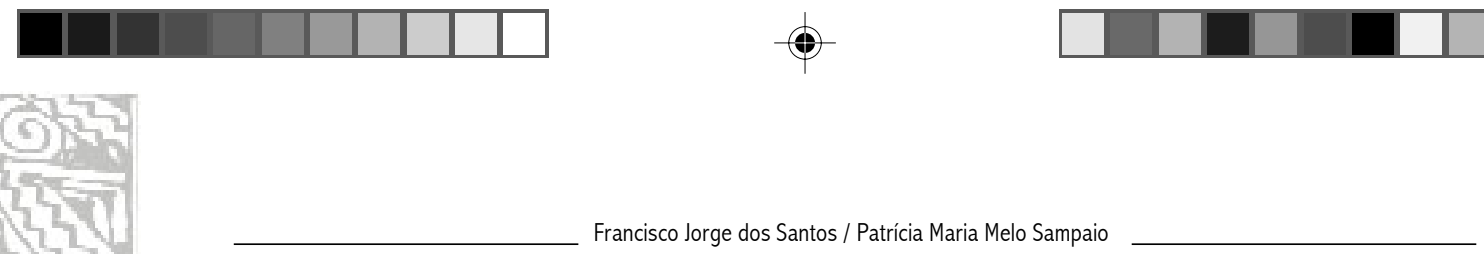

Francisco Jorge dos Santos / Patrícia Maria Melo Sampaio

não possuía tal confirmação. [...] Este episódio prosaico escondia uma situação complexa: cerca de 1/3 dos ocupantes dos postos de capitães, tenentes e alferes da Capitania do Rio Negro eram lideranças indígenas (Principais) que haviam saído destes sertões com seus índios, filhos de Principais já moradores destas Povoações e, por fim, filhos de colonos casados com as primeiras famílias dos mesmos Principais (SAMPAIO, 2007, p. 50-51).

Independentemente do modo e da situação em que exerceriam os cargos públicos da administração colonial, torna-se lícito sugerir que, através dos atos formais metropolitanos, o segmento social indígena começou a ter acesso a um novo modo de governar; ou seja, o modo ocidentalizado de governação que, às duras penas, como se pode inferir pelos dados relacionados acima, as gerações subseqüentes, miscigenadas ou não, foram dando conta dos meandros políticos, jurídicos e administrativos da colônia, que desaguou na sociedade nacional brasileira.

\section{Companhia Geral do Comércio do Grão-Pará e Maranhão}

Conforme Manuel Nunes Dias, até meado do século XVIII, a Amazônia permaneceu quase esquecida pela Coroa portuguesa. A inexistência de atividade econômica multiplicadora de riqueza social obrigava cada família a abastecer-se a si mesma. O imenso espaço tropical parecia estar condenado à ruína. Dir-se-ia que a Amazônia vivia abandonada à própria sorte. Muita terra e poucos braços (DIAS, 1970, 252). Esse quadro econômico constituía mais um elemento do problema criado pelos portugueses, e que teriam que resolver, considerando o projeto de engendrar uma sociedade luso-amazônica; como já dissemos acima, para "dar conta da produção de riqueza, para sanar as mazelas econômicas do Reino". A saída seria a instituição de um organismo que promovesse o crescimento econômico da região.

Assim, foi criada a Companbia Geral do Comércio do Grão-Pará e Maranbão, em 6 de junho de 1755, a qual, de acordo com António Carreira, tinha como meta "acudir o estado caótico da economia do Grão-Pará e Maranhão, derivado da falta de braços e, por forma de assegurar o abastecimento em mercadorias essenciais, por meio de carreiras regulares de navios de Portugal"' (CARREIRA, 1983, p. 35). Para tanto, a Companhia tinha como proposta a introdução de escravos africanos a crédito, dina-

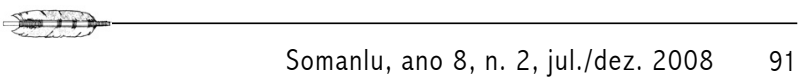


mizar a agricultura e incrementar o comércio, assim como promover um povoamento, através da imigração de casais açorianos, e eliminar as atividades dos comissários volantes, que atuavam como intermediários entre as praças coloniais e metropolitanas. Na década de 1770 os fundos da Companhia pombalina foram utilizados pela Coroa portuguesa para expandir a sua presença militar e administrativa na região, construindo fortes, por exemplo. A Companhia construiu igualmente navios de guerra para proteger as suas frotas.

No entanto, como outras companhias monopolistas, (Companhia Geral de Pernambuco e Paraíba e a do Grão-Pará e Maranhão), perdeu os seus privilégios de monopólio depois da queda de Pombal. Em 5 de janeiro de 1778, D. Maria I deu por terminado o privilégio exclusivo do comércio e navegação da sociedade pombalina, tal era a sua identificação com aquele governo. Mas os novos setores de exportação continuaram a expandir-se depois do desmantelamento da Companhia Geral do Comércio do Grão-Pará e Maranhão, em 1778 (Cf. BROWN, 1994, p.192-194). Maranhão, mas como disse Patrícia M. Sampaio "Falar da companhia pombalina requer uma cautela inicial [...]. A política pombalina, de modo geral, tem gerado avaliações bastante apaixonadas e isso vale tanto para a sua exaltação quanto para sua detratação. De todos, a avaliação da Companhia é um dos seus temas mais polêmicos”. Continua a autora: “Autores como Manuel Nunes Dias e João Lúcio d’Azevedo são exemplares na apresentação de um quadro polarizado" (SAMPAIO, 2001, p.167).

Vejamos por exemplo a clássica opinião de João Lúcio de Azevedo emitida originalmente na publicação de 1901:

No dia 6 de junho de 1755, anniversario do rei, se publicou o decreto, instituindo a companhia, a quem entregava, nas duas províncias, o monopólio da navegação, do commercio externo, e do trafico de negros. Era isto o inicio da ruina dos commissarios e armadores de navios, que mantinham o trafego com o Pará-Maranhão, e ao mesmo tempo dos pequenos negociantes, estabelecidos

92 Somanlu, ano 8, n. 2, jul./dez. 2008 

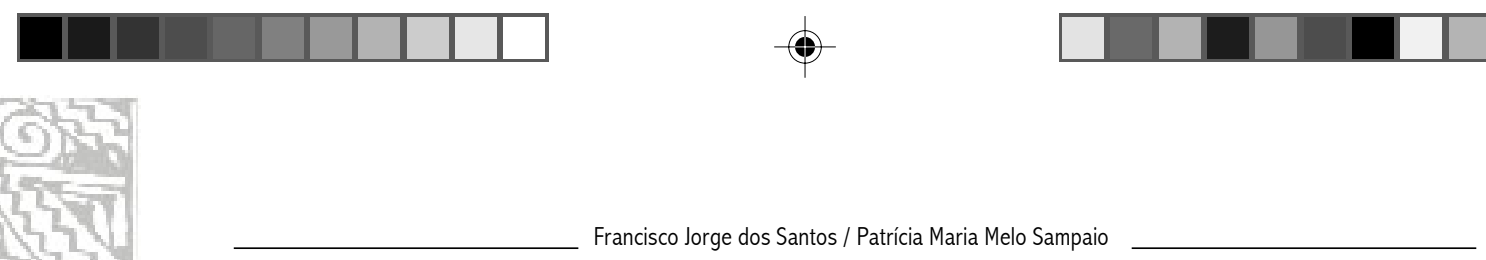

na colonia [...]. Pode-se dizer, emfim, que em todos os grupos sociais foi geral a reprovação (AZEVEDO, 1999, p. 247).

Contudo, de acordo com Manuel Nunes Dias “a produção exportável tropical pôde firmar-se graças às condições criadas pela Companhia, única instituição capacitada à exploração monopolizadora do tráfico atlântico. O cultivo do cacau, café, algodão, arroz, tabaco, feijão, milho e açúcar, especialmente os quatro primeiros, foram intensificados". Esse autor chegou à conclusão de que a Companhia internacionalizou a economia da Amazônia portuguesa:

O algodão e o arroz, que nunca tinham sido objeto de exportação, começaram a girar [...] engrossando as rotas atlânticas do mercantilismo pombalino que demandavam as praças do Báltico, do Mar do Norte e do Mediterrâneo (DIAS, 1970, v. 2, p. 259-260).

Entre uma e outra opinião um flagrante que serpenteia a trajetória da Companhia:

A companhia pombalina, além de dinamizar a produção regional (cacau, café, arroz [e] algum açúcar), introduziu, em pouco mais de duas décadas, 14.749 escravos no Grão-Pará: mas, mesmo com amplas facilidades de créditos a longo prazo que oferecia, a pobreza local fez com que a maior parte de tais africanos fosse reexportado via navegação fluvial para o Mato Grosso e suas minas (CARDOSO, 1996, p. 109-110).

Finalmente, nesse mesmo viés, Arthur Reis, no prefácio da obra de Manuel Nunes Dias, foi categórico ao afirmar que a Companhia Geral do Comércio do Grão-Pará e Maranhão, "inegavelmente, foi útil, serviu o extremo-norte, serviu bem. Ficaram seus frutos. A primeira página do que chamamos hoje de valorização da Amazônia, encontra-se no que ela promoveu" (REIS, 1970, p. 22).

\section{Considerações Finais}

A partir de 1750, a Coroa portuguesa, movimentada por uma conjuntura vivida, ao mesmo tempo, na Europa e na América do Sul, deu início a um processo de redefinição na sua relação metrópole-colônia; por exemplo, a Amazônia, que até então vinha se

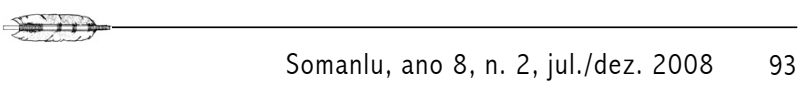


constituindo em área nitidamente marginal nessa relação, passou a ingressar mais efetivamente no espaço político-econômico português e a receber a intervenção direta da metrópole. A nomeação de Mendonça Furtado para o governo do Estado colonial, a mudança da sede do governo de São Luís para Belém e a edição das leis de 1755, confirmam a nova atitude de Lisboa em relação à Amazônia?

O conjunto de leis publicado em 1755 encerrou uma hegemonia religiosa nascida com a publicação do Regimento das Missões do Maranhão e Pará, em 1686, período que Antonio Porro denominou de a idade do ouro da economia missionária, pois a ação dos religiosos não sofrera concorrência à altura, nem do Estado português, tampouco da iniciativa privada. Por conseguinte, esse conjunto de leis, além de interromper a supremacia da Igreja na região, se tornou a espinha dorsal do Diretório dos Índios e de quase todos os ideários político-administrativos, econômicos, social, sobretudo, indigenistas dos diferentes tipos de Estados subseqüentes, seja colonial, imperial ou da república brasileira.

Com base na releitura que se faz hoje sobre as coisas da Colônia, é lícito dizer que as leis de 1755 concebidas em Portugal para a Amazônia sofreram "melhorias" devido ao contexto colonial, até tomar a forma do Diretório dos Índios de 1757. Como afirma Mauro C. Coelho: “o Diretório dos índios é, portanto, uma lei nascida na Colônia formulada em resposta aos conflitos vividos durante o governo de Francisco Xavier de Mendonça Furtado. Ele representou uma nova associação de interesses, distintas da que havia até então" (COELHO, 2005, p. 3637). Não obstante, a Amazônia portuguesa, a partir de então, seguiu o seu rumo histórico ditado por uma regulamentação de Estado, e por ele vigiado, tanto para premiar quanto para punir; em 1798, outra regulamentação substitui aquela, ainda mais rígida. Talvez isso tenha contribuído para forjar o caráter e a natureza cultural das populações amazônicas.

Parodiando o título de uma obra clássica de Charles R. Boxer, diríamos que as chamadas medidas pombalinas inauguraram "a idade da lei e das dores de crescimento de uma sociedade colonial na Amazônia". 


\section{Notas}

1. Parece que o termo Amazônia surgiu em fins da segunda metade do século XIX, na obra do Barão de Santa-Anna Nery, Lepays des Amazones - LEl dorado, les terres a caoutchouc (1884-1885), para designar conjuntamente as províncias do Pará e do Amazonas.

2. Isso não quer dizer que haja uma linha de descendência direta dos casamentos pombalinos com os atuais homens amazônicos, notadamente das populações ribeirinhas ou "cabocas", tendo em vista que, entre estas e aquelas, existe um hiato temporal de longa duração.

3. "Indios aldeados ou reduzidos consideramos os indígenas que já estavam fora de suas aldeias de origem - por descimentos ou outras formas de recrutamento - e que se encontravam misturados com outras etnias, nos aldeamentos próximos ou nos próprios núcleos coloniais administrados por agentes leigos ou religiosos do Estado português. Portanto, já iniciados na fé cristã e portadores de alguns elementos da cultura ocidental" (SANTOS, 2002, p. 26).

4. "Índios gentios eram os indígenas que na época não tinham qualquer relação com os colonizadores, ou que ainda estavam travando os seus primeiros contatos com os portugueses. Portanto, índios que estavam na periferia da chamada civilização ocidental. Para os colonizadores e os dicionários antigos e modernos, "gentio" é aquele que professa a religião pagã, idólatra, bárbaro, selvagem, gente baixa, e outros adjetivos similares” (SANTOS, 2002, p. 24).

5. Na documentação do século XVIII aparece um segmento de índios aldeados definidos como ribeirinhos. Mauro C. Coelho diz que a "alcunha de ribeirinho se deve à constatação do pouco respeito que manifestavam em relação às autoridades, incluindo o próprio Principal"; diz, também, que "tornar-se ribeirinho, isto é, infenso à autoridade colonial, livre da tutela dos diretores, foi, portanto, o objetivo de muitos índios que decidiram pela vida nas povoações” (COELHO, 2006, p. 278-279). A concepção atual da categoria de ribeirinho decorre da proximidade com os rios, o que parece ser diferente do ponto de vista histórico; desse modo, a construção histórica dessa categoria precisa ser enfrentada pela pesquisa cientifica, como sugere Mauro Coelho.

6. Não confundir com o índio Tapuia, muito veiculado na grande historiografia brasileira, ao referir-se aos índios não-tupi ou aos "inimigos" dos brancos da costa leste da América portuguesa, como afirma um especialista: “O universo dos Tapuias, então, é percebido em oposição ao mundo Tupi” (POMPA, 2003, p. 221). 
7. Não obstante a literatura especializada definir o índio aldeado como "genérico", o que implica numa "homogeneização cultural", ainda que isso esteja no horizonte da questão, as pesquisas recentes elaboradas por antropólogos e historiadores apontam para outro rumo, pois, as identidades indígenas não desapareceram definitivamente ao longo da história do contato. A Cabanagem é só um exemplo disso.

8. "O período posterior a 1870 assinala o início do fim do tapuio, como categoria social específica e singular no quadro das comunidades indígenas da Amazônia" (MOREIRA NETO, 1988, p. 102).

9. A mudança de atitude em relação à Amazônia pode ser pensada, também, a partir das nomeações subseqüentes de seus capitães-generais para o exercício do governo do Estado, por exemplo: além de Mendonça Furtado, Manuel Bernardo de Mello e Castro, irmão de Martinho de Mello e Castro, secretário de Estado da Marinha e Ultramar; João Pereira Caldas, filho de um antigo governador do Maranhão; D. Francisco Maurício de Sousa Coutinho, filho de Francisco Inocêncio de Sousa Coutinho, governador de Angola e Benguela e embaixador, na Espanha e, sobrinho de D. Rodrigo de Sousa Coutinho, conde de Linhares e secretário de Estado da Marinha e Ultramar; D. Marcos de Noronha e Brito, 8. $^{\circ}$ conde dos Arcos e futuro vice-rei do Brasil etc.

\section{Referências}

ALMEIDA, Heloísa de Almeida. O Diretório dos Índios - um projeto de "Civilização" no Brasil do século XVIII. Brasília: Editora da UnB, 1997.

AZEVEDO, João Lúcio de. Os Jesuitas no Grão-Pará - suas missões e a colonização. Belém: Secult, 1999 (Fac-símile da edição de 1901).

AMAZONAS, Lourenço da Silva Araújo e. Dicionário topográfico, histórico, descritivo da Comarca do Alto Amazonas. Manaus: ACA-Fundo editorial, 1984 (Fac-símile da edição de 1852).

BEOZZO, José Oscar. Leis e regimento das missões - política indigenista no Brasil. São Paulo: Loyola, 1983.

BIBLIOTECA DIGITAL DA CÂMARA DOS DEPUTADOS - Centro de Documentação e Informação [Brasília]: 2009. Disponível em: <http:// db.camara.gov.br> Acesso em 2009.

96 Somanlu, ano 8, n. 2, jul./dez. 2008

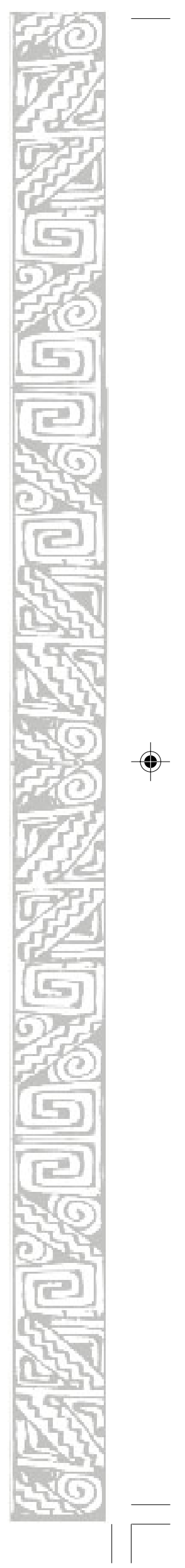


BROWN, Larissa V. Companhia Geral do Grão-Pará e Maranhão (1755-1788). In: SILVA, Maria Beatriz Nizza da (Coord.). Dicionário da história da colonização portuguesa no Brasil. Lisboa: Verbo, 1994.

CARREIRA, António. As Companbias Pombalinas. Lisboa: Editorial Estampa,1988

COELHO, Mauro Cezar. O diretório dos índios e as chefias indígenas: uma inflexão. Campos, Curitiba. v. 7, n. 1, p. 117-134, 2006.

COELHO, Mauro Cezar. Do Sertão para o Mar - Um estudo sobre a experiência portuguesa na América, a partir da Colônia: o caso do Diretório dos índios (1750-1798). Tese (Doutorado) - São Paulo: Universidade de São Paulo, 2005.

CARDOSO, Ciro Flamarion S. A Crise do Colonialismo Luso na América Portuguesa (1750-1822). In: LINHARES, Maria Yedda (Org.). História geral do Brasil. 6. ed. Rio de Janeiro: Campus, 1996, p. 101-124.

DIAS, Manuel Nunes. Fomento e mercantilismo: a companbia geral do comércio do Grão-Paráe Maranhão (1755-1778). Belém: UFPA, 1970, 2 v.

DOMINGUES, Ângela. Quando os indios eram vassalos. Colonização e relações de poder no Norte do Brasil na segunda metade do século XVIII. Lisboa: Comissão Nacional para as Comemorações dos Descobrimentos Portugueses, [s.d].

FERREIRA, Alexandre Rodrigues. Viagem filosófica ao Rio Negro. 2. ed. Manaus: Edua, 2007.

FLEXOR, Marie Helena Ochi. O Diretório dos Índios do Grão-Pará e Maranhão e o Diretório Indiano. Politéia: história e sociedade. Vitória da Conquista, v. 2, n. 1, p. 167 183, 2002.

MALHEIRO, Agostinho M. Perdição. A Escravidão no Brasil - ensaio históricojurídico-social. São Paulo: Edições Cultura, 1944.

MENDONÇA, Marcos Carneiro de. A Amazônia na Era Pombalina. 2. ed. Brasília: Edições do Senado Federal, 2005, 3t.

MOREIRA NETO. Carlos de Araújo. Índios da Amazônia - da maioria a minoria (1750-1850). Petrópolis (RJ): Vozes, 1988.

POMPA, Cristina. Religião como tradução: missionários, Tupi e Tapuia no Brasil colonial. Bauru (SP): Edusc, 2003.

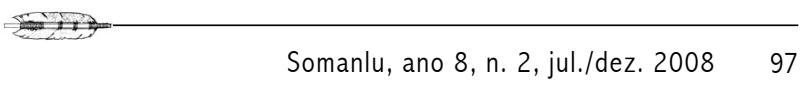


REIS, Arthur de Cezar Ferreira. Lobo d'Almada, um estadista colonial. 3. ed. Manaus: Valer, 2006.

REIS, Arthur de Cezar Ferreira. A Política de Portugal no Valle Amazônico. 2. ed. Belém: Secult, 1993.

REIS, Arthur de Cezar Ferreira. História do Amazonas. 2. ed. Belo Horizonte: Itatiaia. 1989.

REIS, Arthur de Cezar Ferreira. Prefácio. In: DIAS, Manuel Nunes. Fomento e mercantilismo: a companhia geral do comércio do Grão-Pará e Maranhão (1755-1778). Belém: UFPA, 1970. v. 2.

SAMPAIO, Francisco Xavier Ribeiro de. As Viagens do Owidor Sampaio (1774-1775). Manaus: ACA-Fundo Editorial, 1985.

SAMPAIO, Patrícia Maria Melo. Vossa Excelência mandará o que for servido...: políticas indígenas na Amazônia Portuguesa do final do século XVIII. Tempo, Niterói, v. 12, n. 23 , p. 49-65, 2007.

SAMPAIO, Patrícia Maria Melo. Espelhos partidos - etnia. Legislação e desigualdades na Colônia. Sertão do Grão-Pará, c.1755 - c. 1823. Tese (Doutorado) - Niterói: Universidade Federal Fluminense, 2001.

SANTOS, Francisco Jorge dos Santos. Além da conquista - guerras e rebeliões indígenas na Amazônia pombalina. Manaus: Edua, 2002.

SILVA, Maria Beatriz Nizza da. Sistema de casamento no Brasil Colonial. São Paulo: T.A. Queiroz/Edusp, 1984.

VERÍSSIMO, José. As populações indígenas e mestiças da Amazônia. Revista do Instituto bistórico e Geográfico Brasileiro, Rio de Janeiro, tomo 50, p. 295-390, 1987. 